\title{
Atmospheric bromoform at Mace Head, Ireland: seasonality and evidence for a peatland source
}

\author{
L. J. Carpenter ${ }^{1}$, D. J. Wevill ${ }^{1}$, S. O'Doherty ${ }^{2}$, G. Spain ${ }^{3}$, and P. G. Simmonds ${ }^{2}$ \\ ${ }^{1}$ Department of Chemistry, University of York, York, YO10 5DD, UK \\ ${ }^{2}$ School of Chemistry, University of Bristol, Bristol, BS8 1TS, UK \\ ${ }^{3}$ Department of Physics, NUIGalway, Galway, Ireland
}

Received: 21 June 2005 - Published in Atmos. Chem. Phys. Discuss.: 15 August 2005

Revised: 21 October 2005 - Accepted: 21 October 2005 - Published: 2 November 2005

\begin{abstract}
In situ atmospheric observations of bromoform $\left(\mathrm{CHBr}_{3}\right)$ made over a 2.5 year period at Mace Head, Ireland from May 2001- Dec 2003, including during the NAMBLEX (North Atlantic Marine Boundary Layer Experiment) campaign, show broad maxima from spring until autumn and winter minima, with mixing ratios of $5.3+1.0 \mathrm{pptv}$ (mid March - mid October) and 1.8+0.8 pptv (DecemberFebruary). This indicates that, unlike $\mathrm{CHCl}_{3}$, which has a summer minimum and winter maximum at Mace Head, local biological sources of $\mathrm{CHBr}_{3}$ have a greater influence on the atmospheric data than photochemical decay during longrange transport. The emission sources are predominantly macroalgal, but we find evidence for a small terrestrial flux from peatland ecosystems, which so far has not been accounted for in the $\mathrm{CHBr}_{3}$ budget. Sharp increases in $\mathrm{CHCl}_{3}$ and $\mathrm{CHBr}_{3}$ concentrations and decreases in $\mathrm{O}_{3}$ concentrations occurred at night when the wind direction switched from an ocean- to a land-based sector (land breeze) and the wind speed dropped to below $5 \mathrm{~ms}^{-1}$. These observations infer a shallow atmospheric boundary layer with increased $\mathrm{O}_{3}$ deposition and concentration of local emissions of both $\mathrm{CHCl}_{3}$ and $\mathrm{CHBr}_{3}$. The ratio of $\Delta \mathrm{CHCl}_{3} / \Delta \mathrm{CHBr}_{3}$ varied strongly according to the prevailing wind direction; from $0.60+0.15$ in south-easterly $\left(100-170^{\circ}\right)$ and northerly (340$20^{\circ}$ ) air to $2.5+0.4$ in north-easterly $\left(40-70^{\circ}\right)$ air. Of these land-sectors, the south-easterly air masses are likely to be strongly influenced by macroalgal beds along the coast and the emission ratios probably reflect those from seaweeds in addition to land sources. The north-easterly airmasses however had an immediate fetch inland, which locally is comprised of coastal peatland ecosystems (peat bogs and coastal conifer plantations), previously identified as being strong
\end{abstract}

Correspondence to: L. J. Carpenter

(ljc4@york.ac.uk) sources of atmospheric $\mathrm{CHCl}_{3}$ under these conditions. Although we cannot entirely rule out other local land or coastal sources, our observations also suggest peatland ecosystem emissions of $\mathrm{CHBr}_{3}$. We use correlations between $\mathrm{CHCl}_{3}$ and $\mathrm{CHBr}_{3}$ during the north-easterly land breeze events in conjunction with previous estimates of local wetland $\mathrm{CHCl}_{3}$ release to tentatively deduce a global wetland $\mathrm{CHBr}_{3}$ source of $20.4(0.4-948) \mathrm{Gg} \mathrm{yr}^{-1}$, which is approximately $7 \%$ of the total global source.

\section{Introduction}

Bromoform is ubiquitous in the marine environment and is the major natural carrier of organic bromine to the atmosphere. It has a relatively short tropospheric lifetime of $\sim 3$ weeks and is believed to make a significant contribution to inorganic bromine in the upper troposphere and lower stratosphere (Sturges et al., 2000; Nielsen and Douglass, 2001; von Glasow et al., 2004). The major sources of $\mathrm{CHBr}_{3}$ have been identified as marine in origin, namely macroalgae, ocean phytoplankton and water chlorination (Gschwend et al., 1985; Carpenter and Liss, 2000; Quack and Wallace, 2003 and references therein). To date, there are only limited and inconclusive studies of production by terrestrial ecosystems. $\mathrm{CHBr}_{3}$ has been found in the air of upper soil of a pristine spruce forest (Haselmann et al., 2000). However in soil air of rural areas, Hoekstra et al. (1998) found no detectable concentrations of $\mathrm{CHBr}_{3}$, except after in-situ enrichment by $\mathrm{KBr}$. This suggests the potential of soils containing elevated bromide, e.g. coastal soils/peatlands, to produce brominated trihalomethanes. Peat bogs cover approximately $3 \%$ of the total continental land mass (Biester et al., 2004). They are comprised exclusively of organic matter and in additional

(C) 2005 Author(s). This work is licensed under a Creative Commons License. 
coastal bogs are subject to deposition of halides from sea spray, making such sites potentially significant organohalogen producers. Biester et al. (2004) found that the majority of halogens in peat exist in an organically bound form, with concentrations dependent upon peat decomposition processes. Speciated organohalogens were however not identified in this study.

Chloroform concentrations at Mace Head can be substantially influenced by local biological emissions from the pine forests and peat bogs, which cover large parts of Ireland (Dimmer et al., 2001; O'Doherty et al., 2001). Extrapolating from chamber studies made on Irish peatland ecosystems, Dimmer et al. (2001) estimated global annual fluxes of 4.7 (0.1-151.9) $\mathrm{Gg} \mathrm{yr}^{-1}$ of $\mathrm{CHCl}_{3}$ from such systems and $24.1 \mathrm{Gg} \mathrm{yr}^{-1}$ from total wetlands. $\mathrm{CHBr}_{3}$ measurements were not made in the latter study. Here, we present over 2.5 years of $\mathrm{CHBr}_{3}$ data measured at Mace Head and use the tracer-ratio technique, in conjunction with the data from Dimmer et al. (2001), to estimate the contribution of peatland and wetlands to global $\mathrm{CHBr}_{3}$ emissions.

\section{Experimental}

\subsection{Site description}

Mace Head is located on the remote western coast of County Galway, Ireland $\left(53^{\circ} 19^{\prime} \mathrm{N}, 9^{\circ} 54^{\prime} \mathrm{W}\right)$. The site is well known for background air measurements and receives relatively clean marine air from the prevailing westerly sector associated with the easterly tracking cyclonic systems of the North Atlantic. The surrounding area is sparsely populated and contains a large expanse of peat bogs. The nearest large population centre is Galway, $\sim 62$ miles to the east. Heard et al. (2005) gives a full description of the site.

\subsection{Instrumentation}

The York halocarbon measurements were made during the NAMBLEX campaign (2 August-3 September 2002) with a Perkin Elmer Turbomass GC-MS system with electron impact ionisation and operating in selective ion recording mode. Air sampling was from a height of $20 \mathrm{~m}$ through a stainless steel 3/4" manifold, pumped at $\sim 30 \mathrm{~L} \mathrm{~min}^{-1}$. Sample volumes of $500 \mathrm{~mL}$ were pre-concentrated on a two stage carbon-based adsorbent trap held at $-10^{\circ} \mathrm{C}$ before being transferred to the $\mathrm{GC}$ by rapid heating to $400^{\circ} \mathrm{C}$. Halocarbons were separated on a SGE BPX5 capillary column (50 $\mathrm{m} \times 0.32 \mathrm{~mm}$ i.d. $\times 3 \mu \mathrm{m}$ d.f.). Detection limits are between 0.02 and $0.12 \mathrm{pptv}$ for approximately hourly samples of $\mathrm{CHCl}_{3}, \mathrm{CH}_{3} \mathrm{I}, \mathrm{C}_{2} \mathrm{H}_{5} \mathrm{I}, 1-\mathrm{C}_{3} \mathrm{H}_{7} \mathrm{I}, 2-\mathrm{C}_{3} \mathrm{H}_{7} \mathrm{I}, \mathrm{CH}_{2} \mathrm{ClI}, \mathrm{CH}_{2} \mathrm{Br}_{2}$, $\mathrm{CHBr}_{2} \mathrm{Cl}, \mathrm{CH}_{2} \mathrm{BrI}, \mathrm{CHBr}_{3}$ and $\mathrm{CH}_{2} \mathrm{I}_{2}$ with a precision of $3-8 \%$ (5\% for $\left.\mathrm{CHBr}_{3}\right)$ and complete recovery of all compounds. Our calibration system utilises fixed volume $(50 \mu \mathrm{l})$ loop injections of the output of thermostatted in-house permeation tubes filled with pure liquids ( $\geq 97 \%$ purity, Aldrich,
UK) into a $100 \mathrm{ml} \mathrm{min}^{-1}$ stream of purified nitrogen gas in order to dilute parts per million by volume (ppmv) mixing ratios into low parts per trillion by volume (pptv). The calibration is completely automated, allowing multi-point calibrations during routine operation. The overall accuracy of the measurements is estimated to be $\pm 15 \%$. A full description of the calibration and GC-MS methodology is given in Wevill and Carpenter (2004).

Routine AGAGE (Advanced Global Atmospheric Gases Experiment) GC-MS observations, made by Bristol University, of a range of halocarbons commenced at Mace Head in 1994. A full description of the instrumentation can be found in Prinn et al. (2000) and Simmonds et al. (1995). A nominal, precisely repeatable two liters of ambient air or calibration standard are trapped onto a 3-stage mixed adsorbent contained in a microtrap. The microtrap is located between two thermoelectric coolers maintained at $-50^{\circ} \mathrm{C}$ during sampling. This low temperature enables the small mass of adsorbent material to have the capacity to quantitatively trap the compounds of interest. The trapped sample is purged briefly with clean helium then thermally desorbed $\left(245^{\circ} \mathrm{C}\right)$ directly onto a chromatographic capillary column (CPSil-5, $100 \mathrm{~m} \times 0.32 \mathrm{~mm}$ i.d. $\times 5 \mu \mathrm{m}$ d.f.), interfaced to an Agilent benchtop MS. The individual trace components are separated and identified using both their chromatographic retention times, and their characteristic ion masses. Each component is quantified by integrating the response of a selected target ion and where possible, two qualifier ions are used to ensure compound specific ion ratios are maintained. Custom software developed at Scripps Institution of Oceanography (SIO), enables constant monitoring of ion ratios, peak width ratios and many other diagnostic parameters. This enables rapid identification and determination of instrumental problems. At present standard and air analysis are alternated every two hours to provide six calibrated measurements per day. The method of standard preparation and propagation is described in detail in O'Doherty et al. (2004). Briefly, all working standards are 351 stainless steel electropolished tanks (Essex Cryogenics, Missouri, USA) filled with Mace Head "real-air", under baseline conditions, and have a working life of 3-4 months. Calibration of ambient air measurements is achieved by means of bracketing them with measurements from a working standard tank. At present, a $\mathrm{CHBr}_{3}$ calibration is not assigned for the ADSGC-MS data at Mace Head; the Bristol data presented here were instead calibrated using contemporaneous York $\mathrm{CHBr}_{3}$ data collected at Mace Head, as described below.

2.3 Comparison of York/Bristol measurements and conversion of Bristol $\mathrm{CHBr}_{3}$ relative response to pptv values

An "organic" x-y correlation (i.e. a correlation which minimizes errors in both the $\mathrm{x}$ - and $\mathrm{y}$-directions, e.g. Helsel and Hirsch, 1992) of York/Bristol $\mathrm{CHCl}_{3}$ data taken within the same 40 -min period during the NAMBLEX campaign 

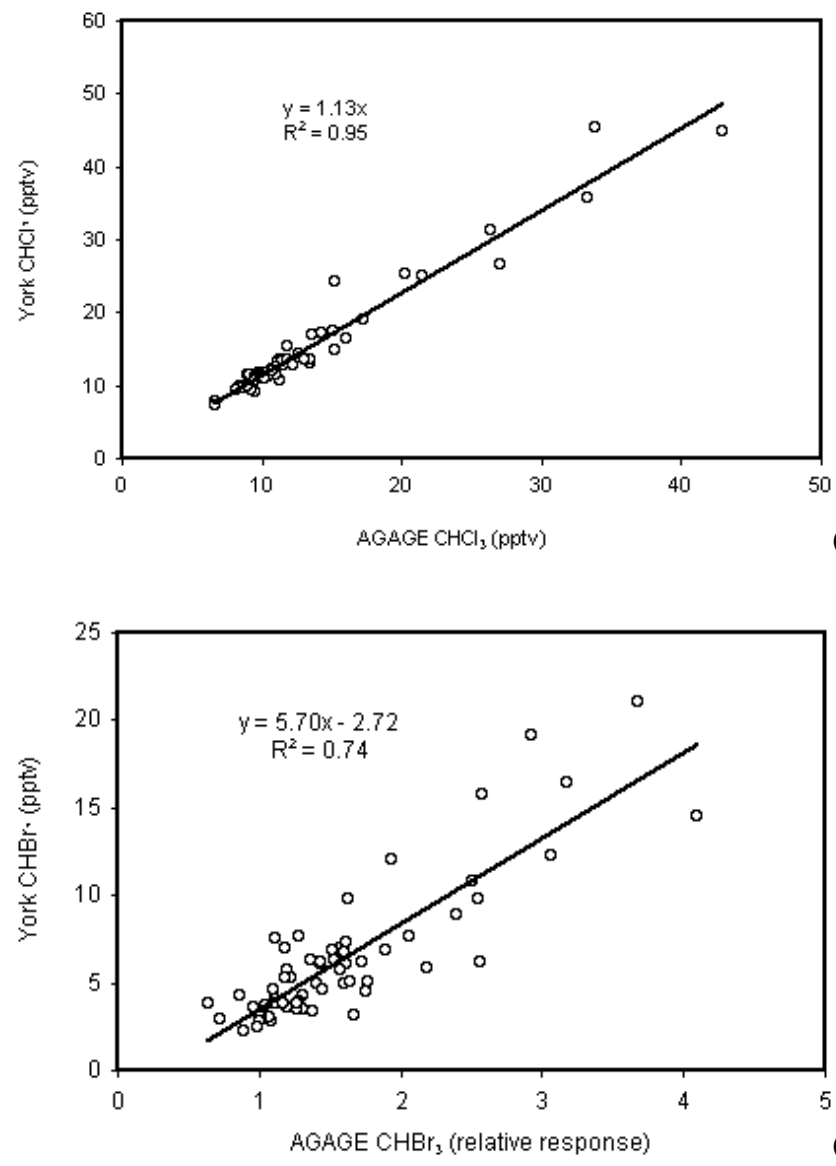

Fig. 1. (a) Organic correlation of York and Bristol $\mathrm{CHCl}_{3}$ mixing ratios measured during the NAMBLEX campaign, using data points taken within the same 40-min period. (b) Organic correlation of York $\mathrm{CHBr}_{3}$ mixing ratios and Bristol $\mathrm{CHBr}_{3}$ relative response data, using data points taken within same 40-min period.

showed that on average the York measurements were $13 \%$ higher than the AGAGE data (with zero offset), with an $R^{2}$ value of 0.95 (Fig. 1a). The fact that the instruments were not sampling for the same time periods may explain some or most of the scatter, however there is clearly also a calibration difference although this is within the estimated error of our measurements.

The same procedure for the correlation of York $\mathrm{CHBr}_{3}$ mixing ratios against the Bristol $\mathrm{CHBr}_{3}$ relative response to a Mace Head reference air sample (contained in a $36 \mathrm{~L}$ electropolished Essex canister) revealed more variance in the linear regression $\left(R^{2}\right.$ value of 0.74$)$ and an offset in the Bristol data (Fig. 1b). Because the York instrument has the same precision for $\mathrm{CHBr}_{3}$ and $\mathrm{CHCl}_{3}$ measurements (Wevill and Carpenter, 2004), we attribute the increased scatter of the correlation compared to Fig. 1a to the shorter lifetime and hence greater natural variability of atmospheric $\mathrm{CHBr}_{3}$. Indeed, both instruments detected greater variability in atmospheric $\mathrm{CHBr}_{3}$ levels during NAMBLEX (relative standard deviation

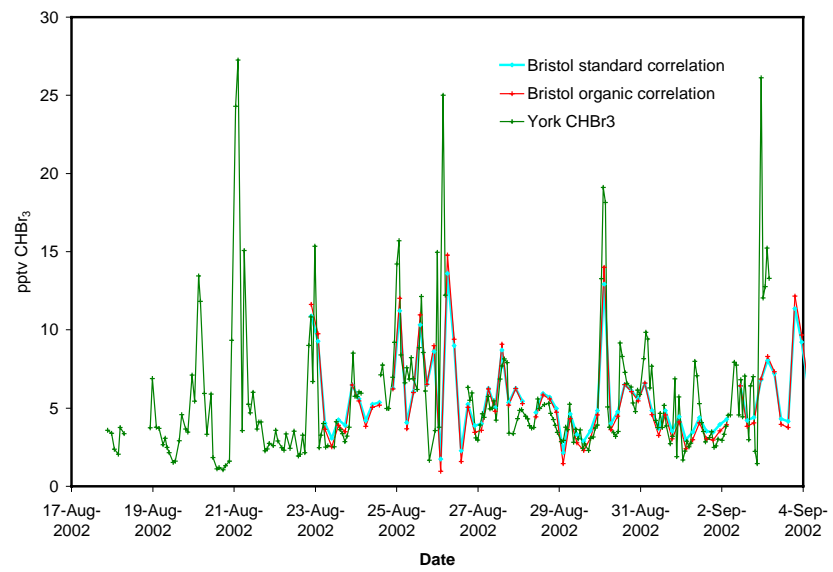

Fig. 2. Comparison of York and Bristol $\mathrm{CHBr}_{3}$ data, converted to mixing ratios using both the organic correlation of Fig. $1 \mathrm{~b}$ and a standard correlation.

of $80 \%$ (York) and $60 \%$ (Bristol)) compared to $\mathrm{CHCl}_{3}$ (relative standard deviation of $50 \%$, both instruments). The offset of the Bristol data may be caused by incomplete recovery of high concentrations of $\mathrm{CHBr}_{3}$ in the microtrap, which was designed for quantitative measurements of the more volatile Halons and CFCs rather than $\mathrm{CHBr}_{3}$. A comparison of the York data with Bristol $\mathrm{CHBr}_{3}$ mixing ratios converted using both the organic regression values and a standard linear least squares regression (with York data on the $\mathrm{x}$-axis) is shown in Fig. 2 and reveals the higher dynamic range of the York data. Although the Bristol instrument appears to underestimate the highest mixing ratios of $\mathrm{CHBr}_{3}$, nevertheless the average concentrations derived using this approach are equal to the York average concentrations. We chose to use a standard correlation to "correct" the Bristol data to mixing ratios because the organic correlation under-predicted low values and in fact resulted in occasional negative mixing ratios in winter.

\subsection{Tracer-ratio approach}

The tracer-ratio technique has been used, in various forms, to estimate trace gas emissions by utilising correlations obtained with a reference compound with a known emission, in this case $\mathrm{CHCl}_{3}$ (e.g. Dunse et al., 2001, 2005; Biraud et al., 2002; Carpenter et al., 2003). Here, we attempt to use $\mathrm{CHBr} 3 / \mathrm{CHCl}_{3}$ correlations obtained during land breeze events in order to estimate Irish terrestrial emissions of bromoform. Visual inspection of the data from Mace Head clearly shows the strong covariance of $\mathrm{CHCl}_{3}, \mathrm{CHBr}_{3}$ and $\mathrm{O}_{3}$ concentrations during land breeze events (e.g. Fig. 3). Although the size and duration of the land breeze episodes varied, a strong temporal correlation in $\mathrm{CHCl}_{3}, \mathrm{CHBr}_{3}$ and $\mathrm{O}_{3}$ and wind direction was always apparent, with only one maximum in $\mathrm{CHCl}_{3}$ and $\mathrm{CHBr}_{3}$. For each "event", defined as described below (Sect. 2.5), the maximum change in 


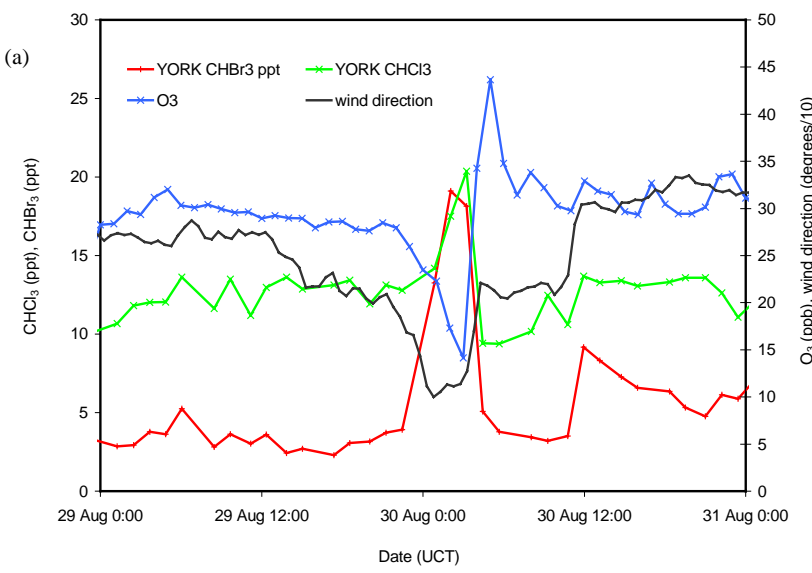

(b)

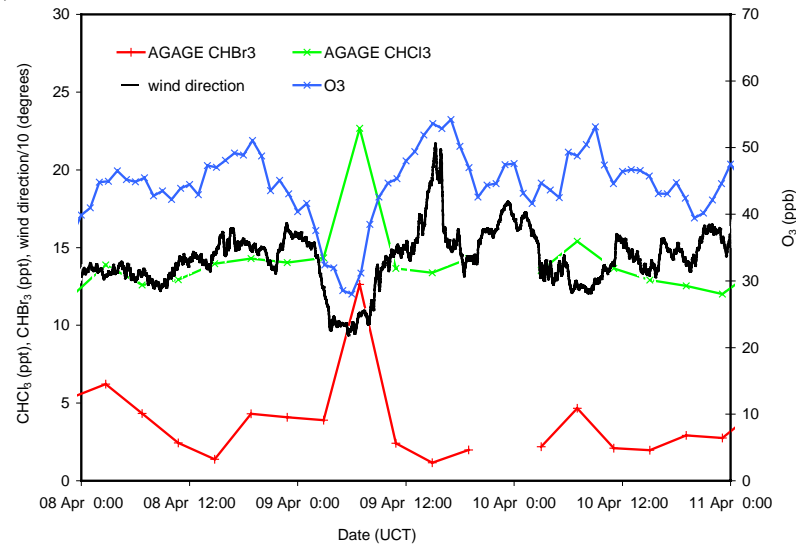

Fig. 3. Land breeze events during the nights of (a) 29/30 August 2002 and (b) 8/9 April 2003

concentration $\Delta X$ (where $X=\mathrm{CHCl}_{3}$ or $\mathrm{CHBr}_{3}$ ) from baseline was calculated, both in units of pptv, yielding one data point for each event. The "baseline" was taken by interpolating between the halocarbon concentrations measured immediately before and after a particular event. We then use the simple approach of assuming a linear relationship between the enhancements in mixing ratio,

$\Delta \mathrm{CHCl}_{3} / \Delta \mathrm{CHBr}_{3}=E$

where $E$ is the molar emission ratio (Dunse et al., 2005) and both $\Delta \mathrm{CHCl}_{3}$ and $\Delta \mathrm{CHBr}_{3}$ are in units of ppt. The overall approach assumes no atmospheric decay along the trajectory, which in this case should apply, given the short fetches (see below). More details concerning the tracer-ratio approach can be found in Dunse et al. (2005).

In order to deduce the mass $(M)$ of emissions, the relative molecular weight $(M W)$ of the two gases should be taken into account:

$M_{\mathrm{CHBr}_{3}}=E \cdot M_{\mathrm{CHCl}_{3}} \cdot\left(M W_{\mathrm{CHBr}_{3}} / M W_{\mathrm{CHCl}_{3}}\right)$

The mass of $\mathrm{CHCl}_{3}$ emissions was obtained from estimates of peatland (coastal marshes and bogs) and total wet-

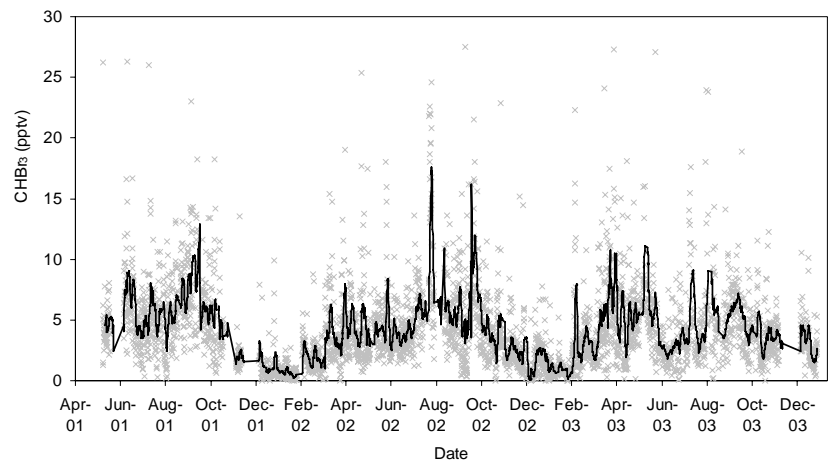

Fig. 4. Bristol $\mathrm{CHBr}_{3}$ data fixed to the York calibration scale. The crosses are individual (approx. 4 hourly) data points and the solid line is a 20-point moving average.

land (peatland plus coastal conifer forest) ecosystem terrestrial sources of $\mathrm{CHCl}_{3}$ at Mace Head (Dimmer et al., 2001), as discussed in Sect. 3.2. Such emissions are believed to be the cause of enhanced chloroform concentrations observed during land breeze episodes at Mace Head (O'Doherty et al., 2001).

\subsection{Identifying local land breeze events}

Land breeze events are quite commonly observed at Mace Head, and are characterised by a change in wind direction from westerly (ocean sector) in the day to easterly (land sector) at night (e.g. O'Doherty et al., 2001; Biraud et al., 2002). They are accompanied by a rapid decrease in $\mathrm{O}_{3}$, due to increased deposition over land and a shallower nocturnal continental boundary layer, and increases in $\mathrm{CHCl}_{3}, \mathrm{CO}_{2}$ and ${ }^{212} \mathrm{~Pb}$ concentrations during low wind speeds due to local emissions (Biraud et al., 2002). Here, we select events within the land sector $\left(20-140^{\circ}\right)$ with a greater than $40 \%$ maximum decrease in $\left[\mathrm{O}_{3}\right]$ and greater than $100 \%$ change in $\left[\mathrm{CHCl}_{3}\right]$. We define the fetch of the land breeze events as the product of their time duration (typically 5-7 h) and the average wind speed recorded during the event (typically $1-5 \mathrm{~ms}^{-1}$ ) and select events with a fetch of $<50 \mathrm{~km}$, i.e. dominated by local continental emissions.

\section{Results and discussion}

\subsection{General trends and seasonality}

The complete Bristol data set, fixed to the York calibration scale as described in Sect. 2.3, is shown in Fig. 4. Broad spring-autumn maxima, with occasional peaks of over 25 pptv but an average of $\sim 5$ pptv, and winter minima are apparent. Figure 5 shows an averaged annual cycle for $\mathrm{CHBr}_{3}$ based upon 2.5 years of data, comprising 2-weekly average data points, with mixing ratios of $5.3 \pm 1.0 \mathrm{pptv}$ (mid Marchmid October) and $1.8 \pm 0.8$ pptv (December-February). Also 
shown is an average UVB $(290-320 \mathrm{~nm})$ annual cycle computed for Mace Head. The only other published annual measurements of $\mathrm{CHBr}_{3}$ have been made at the free tropospheric site of Mauna Loa (Atlas and Ridley, 1996, discussed in Nielsen and Douglass, 2001) and at Alert, in the Arctic boundary layer (Yokouchi et al., 1996). Both these studies showed winter maxima and summer minima, suggesting higher reactive loss in summer during long-range transport, but could give little information on the seasonal variation of sources. Thus our data gives a unique insight into the seasonal variation of coastal $\mathrm{CHBr}_{3}$ emissions.

$\mathrm{CHBr}_{3}$ appears to be the most abundant organic halogen compound emitted from macroalgae (e.g. Nightingale et al., 1995; Mtolera et al., 1996; Carpenter et al., 2000) and these emissions are significant on a global scale, comprising probably the dominant source of atmospheric $\mathrm{CHBr}_{3}$ (Carpenter and Liss, 2000). Halocarbon formation in macroalgae is initiated by oxidative stress, resulting in $\mathrm{H}_{2} \mathrm{O}_{2}$ production as part of a defense mechanism (Theiler et al., 1978; Pedersén et al., 1996 and references therein). The formation of polyhalomethanes are initiated by haloperoxidase enzymes produced in the cells, which catalyse the reaction of accumulated halide ions with $\mathrm{H}_{2} \mathrm{O}_{2}$, forming a hypohalous acid. Halogenated species such as $\mathrm{CHBr}_{3}$ may be subsequently formed in the algal cells and transferred across the cell membrane to seawater (Gschwend et al., 1985). Alternatively, formation may be initiated outside the cell by reaction of the released hypohalous acid with organic matter in seawater (Wever et al, 1991).

Macroalgae exhibit quite constant cover over the course of the year, resulting from the continual recruitment of young plants and the prolific output of spores. Our data indicate that $\mathrm{CHBr}_{3}$ emission occurs all year, with only a short winter period of minimal levels (November-February), when the algal population of the intertidal region is at its lowest. Goodwin et al. (1997) and Klick (1993) reported that $\mathrm{CHBr}_{3}$ release from brown macroalgae maximises in mid summer, probably due to enhanced tissue decay during this period. Further, a number of studies have shown that $\mathrm{CHBr}_{3}$ release from macroalgae is stimulated by light (e.g. Klick, 1993; Nightingale et al., 1995; Mtolera et al., 1996; Pedersen et al., 1996; Goodwin et al., 1997; Carpenter et al., 2000). Light-induced stress, especially at high light intensities, results in increased cellular levels of activated oxygen species including hydrogen peroxide, as by-products of oxygenic photosynthesis, which generally increase the emission of halocarbons. Seaweed incubation experiments reveal an enhancement in $\mathrm{CHBr}_{3}$ release by factors of 2-10 in daylight compared to the dark (Mtolera et al., 1996; Pedersen et al., 1996; Carpenter et al., 2000). Thus, variation in light intensities and/or tissue decay, in conjunction with higher algal coverage from early spring through to late autumn, could explain the seasonal variation of $\mathrm{CHBr}_{3}$ at Mace Head.

It is well established that trace gas emissions from phytoplankton tend to peak in spring (at this latitude around early

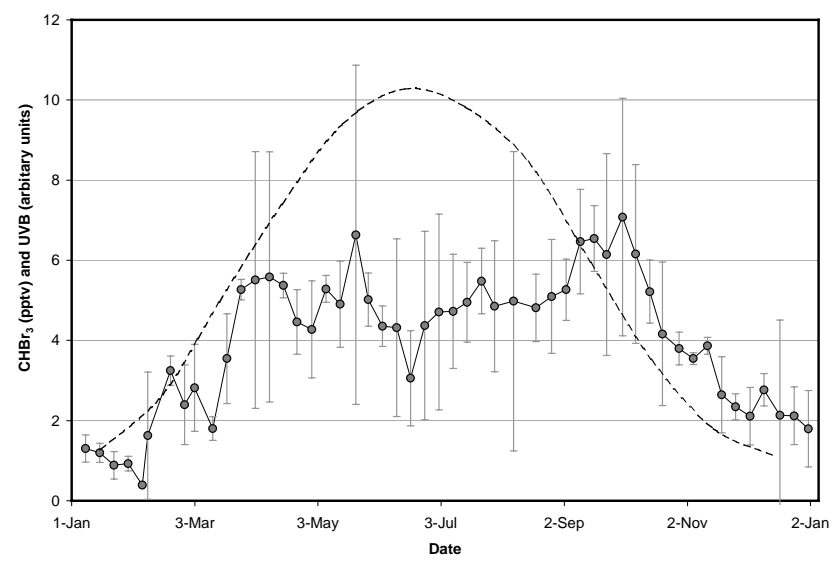

Fig. 5. Mean annual cycle of $\mathrm{CHBr}_{3}$ and UVB at Mace Head. The error bars on the $\mathrm{CHBr}_{3}$ data are the RSDs of the 2-weekly average data points from each year.

May), however the contribution of temperate microalgae to atmospheric $\mathrm{CHBr}_{3}$ levels at Mace Head is probably minimal (Carpenter et al., 2003). The highest $\mathrm{CHBr}_{3}$ concentrations are consistently found along coastlines containing macroalgal beds, with coastal and shelf seawater concentrations of $\mathrm{CHBr}_{3}$ of up to 100 times greater than open ocean concentrations (Quack and Wallace, 2003).

\subsection{Land breeze events}

In total, 28 land breeze events as defined by the selection criteria described in Sect. 2.4 were identified during mid 20012003, all occurring during the period 23:00-04:00. These events were characterised by sharp changes in wind direction (from sea to land), $\left[\mathrm{O}_{3}\right],\left[\mathrm{CHCl}_{3}\right]$ and $\left[\mathrm{CHBr}_{3}\right]$, as typified by the events shown in Fig. 3. The variation in $\mathrm{CHCl}_{3}$ correlated well with the variations in $\mathrm{CHBr}_{3}$ and in $\mathrm{O}_{3}$ during every one of these events. Only on the 29/30 August 2002 (during the NAMBLEX campaign) were sufficient Bristol and York data available for comparison; the excellent agreement of the (corrected) Bristol and York $\Delta \mathrm{CHCl}_{3} / \Delta \mathrm{CHBr}_{3}$ ratios of 0.62 and 0.61 , respectively gives some confidence that both data sets can be used to give an estimate of the emission ratio $E$ in Eq. (1).

Figure 6 shows the $\triangle \mathrm{CHCl}_{3}$ vs. $\triangle \mathrm{CHBr}_{3}$ correlations, separated into events occurring in either coastally-influenced (e.g. south-easterly $\left(100-170^{\circ}\right)$ or northerly $\left(340-20^{\circ}\right)$ ), or north-easterly $\left(40-70^{\circ}\right)$ winds. South-easterly and northerly winds travel across the Irish shoreline and are expected to be strongly influenced by local macroalgal emissions. During such events, the $\triangle \mathrm{CHCl}_{3} / \Delta \mathrm{CHBr}_{3}$ molar ratio was relatively invariant at $0.6 \pm 0.15$, indicating that average emission ratios of $\mathrm{CHCl}_{3} / \mathrm{CHBr}_{3}$ from the local coastline are also relatively constant. Both $\mathrm{CHCl}_{3}$ and $\mathrm{CHBr}_{3}$ are known products of macroalgae (e.g. Nightingale et al., 1995; Carpenter et al., 


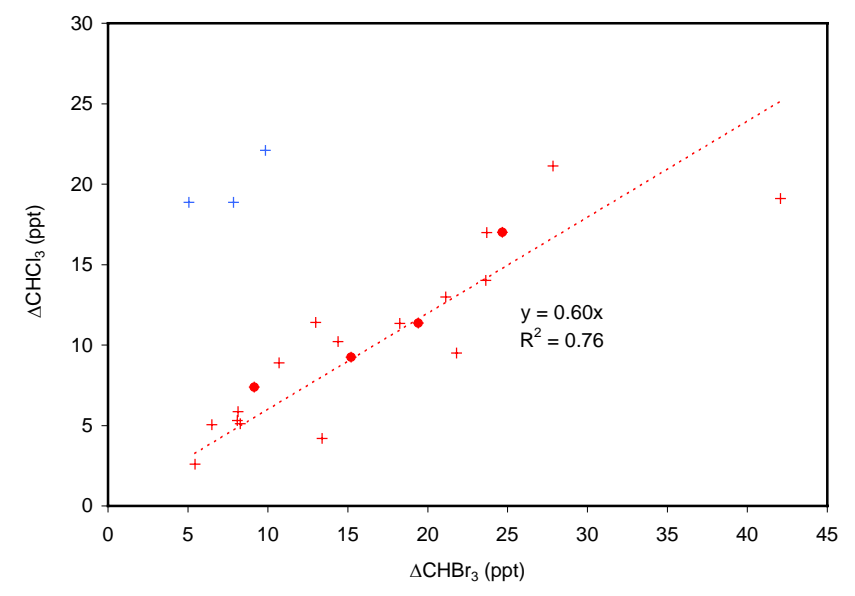

Fig. 6. $\Delta \mathrm{CHCl}_{3} / \Delta \mathrm{CHBr}_{3}$ ratios obtained using both Bristol (crosses) and York (filled circle) data. The red data points were obtained during southeasterly or northerly winds (probable coastal influence); the blue data points were obtained during northeasterly winds, with no apparent immediate coastal influence.

2000 and references therein), with $\mathrm{CHBr}_{3}$ consistently produced in higher amounts across many different genera.

From the north-easterly winds data set, data were selected which back-trajectories (Fig. 7) indicated had an inland fetch with no immediate coastal influence. This selection criterion left 3 data points, as shown in Fig. 6. The $\Delta \mathrm{CHCl}_{3} / \Delta \mathrm{CHBr}_{3}$ molar ratio during these conditions was much higher than the coastally-influenced land-breeze events, with an average value of $2.5 \pm 0.4$. The variance in the ratio may be due to a number of factors including different starting concentrations of $\mathrm{CHCl}_{3}$ and $\mathrm{CHBr}_{3}$ along the trajectories during the various events, and different emission ratios from local terrestrial sources, e.g. peat bogs, inland marshes and coastal forests. Although $\mathrm{CHBr}_{3}$ was not measured, Dimmer et al. (2001) found strikingly different emission ratios of $\mathrm{CHCl}_{3}$ to $\mathrm{CH}_{3} \mathrm{Br}$ in peatland compared to conifer forest in the vicinity of Mace Head, with greater variation still within vegetation types. Thus, although our measurements show evidence of peatland ecosystem sources of $\mathrm{CHBr}_{3}$ at Mace Head, an absolute emission ratio compared to $\mathrm{CHCl}_{3}$ should be treated with caution, not only because of variation within source, but also because of the short atmospheric lifetimes of $\mathrm{CHCl}_{3}$ and $\mathrm{CHBr}_{3}$, and the instrumental issues potentially affecting the Bristol ratios, as discussed in Sect. 2.3. Nevertheless, it is instructive to approximate source strengths from peatland emissions in order to compare with other known source strengths (which are also highly uncertain). Dimmer et al. (2001) estimated a global $\mathrm{CHCl}_{3}$ flux from peatland soil of $4.7(0.1-151.9) \mathrm{Gg} \mathrm{yr}^{-1}$ and from total wetlands of $24.1 \mathrm{Gg} \mathrm{yr}^{-1}$, calculated simply by extrapolating the measured Irish fluxes to estimated global coverages; $1.04 \times 10^{6} \mathrm{~km}^{2}$ for peatbog (Olson, 1992) and $5.3 \times 10^{6} \mathrm{~km}^{2}$ for wetlands (Matthews and Fung, 1987). We use the $1 \sigma$ limits of the molar $\Delta \mathrm{CHCl}_{3} / \Delta \mathrm{CHBr}_{3}$ ratio determined here of 2.5 (2.1-2.9), together with $\mathrm{CHCl}_{3}$ source estimates to deduce a total global $\mathrm{CHBr}_{3}$ peatland source of $54.0(0.1-$ 183) $\mathrm{Gg} \mathrm{yr}^{-1}$ and total wetlands source of 20.4 (0.4-948) $\mathrm{Gg} \mathrm{yr}^{-1}$. Any non-peatland ecosystem sources of either $\mathrm{CHCl}_{3}$ or $\mathrm{CHBr}_{3}$ over the north-easterly fetch will add error to our peatland emission estimates. However, despite the large uncertainties involved, it is worth comparing our peatland and wetland source estimates with current estimates for $\mathrm{CHBr}_{3}$ emission of $220 \mathrm{Gg} \mathrm{yr}^{-1}$ from macroalgae (Carpenter and Liss, 2000) and a total global source of $300 \mathrm{Gg} \mathrm{yr}^{-1}$ (Dvortsov et al., 1999). Thus, it is possible that peatland and wetland emissions of $\mathrm{CHBr}_{3}$ together are a small $(<10 \%)$ but significant unaccounted term in the $\mathrm{CHBr}_{3}$ budget.

\section{Conclusions}

So far, global modelling studies of tropospheric and stratospheric bromine that have specifically included $\mathrm{CHBr}_{3}$ (Dvortsov et al., 1999; Nielsen and Douglass, 2001; von Glasow et al. 2004) have assumed a seasonally invariant ocean source of $\mathrm{CHBr}_{3}$. Our study indicates a much stronger source of $\mathrm{CHBr}_{3}$ in summer than in winter, possibly linked to light levels and macroalgal coverage, and points to an additional coastal terrestrial source in the $\mathrm{CHBr}_{3}$ budget of (tentatively) around $7 \%$ of the global source. The dual roles of such ecosystems in conjunction with macroalgae indicate the dominance of coastal regions in providing $\mathrm{CHBr}_{3}$ to the atmosphere. Changes in wetland emissions, through man's impact on land use, and in ultraviolet radiation at the earth's surface due to the effect of ozone-depleting substances on stratospheric ozone, show the possibility of anthropogenic effects on the release of $\mathrm{CHBr}_{3}$, which itself is an ozone-depleting substance.

Acknowledgements. We specifically acknowledge the cooperation and efforts of the station operators and support staff Gerard Spain and Duncan Brown at Mace Head. We also thank the Physics Department, National University of Ireland, Galway, for making the research facilities and meteorological data at Mace Head available. The operation of the Mace Head station was supported by the National Aeronautic and Space Administration (NASA) (grants NAGW-732, NAG1-1805, NAG5-3974 NAG-12099, to MIT; grants NAGW-2034, NAG5-4023 to SIO), the Department of the Environment, Food and Rural Affairs (UK) (contracts PECD $1 / 1 / 130$ and $7 / 10 / 154$, EPG $1 / 1 / 82$ and EPG $1 / 1 / 130$ to International Science Consultants). The halocarbon component of the NAMBLEX campaign was funded by NERC grant NER/A/S/2001/01064. We gratefully acknowledge the NOAA Air Resources Laboratory (ARL) for providing the HYSPLIT transport and dispersion model. DJW thanks the EPSRC for his studentship.

Edited by: D. Heard 


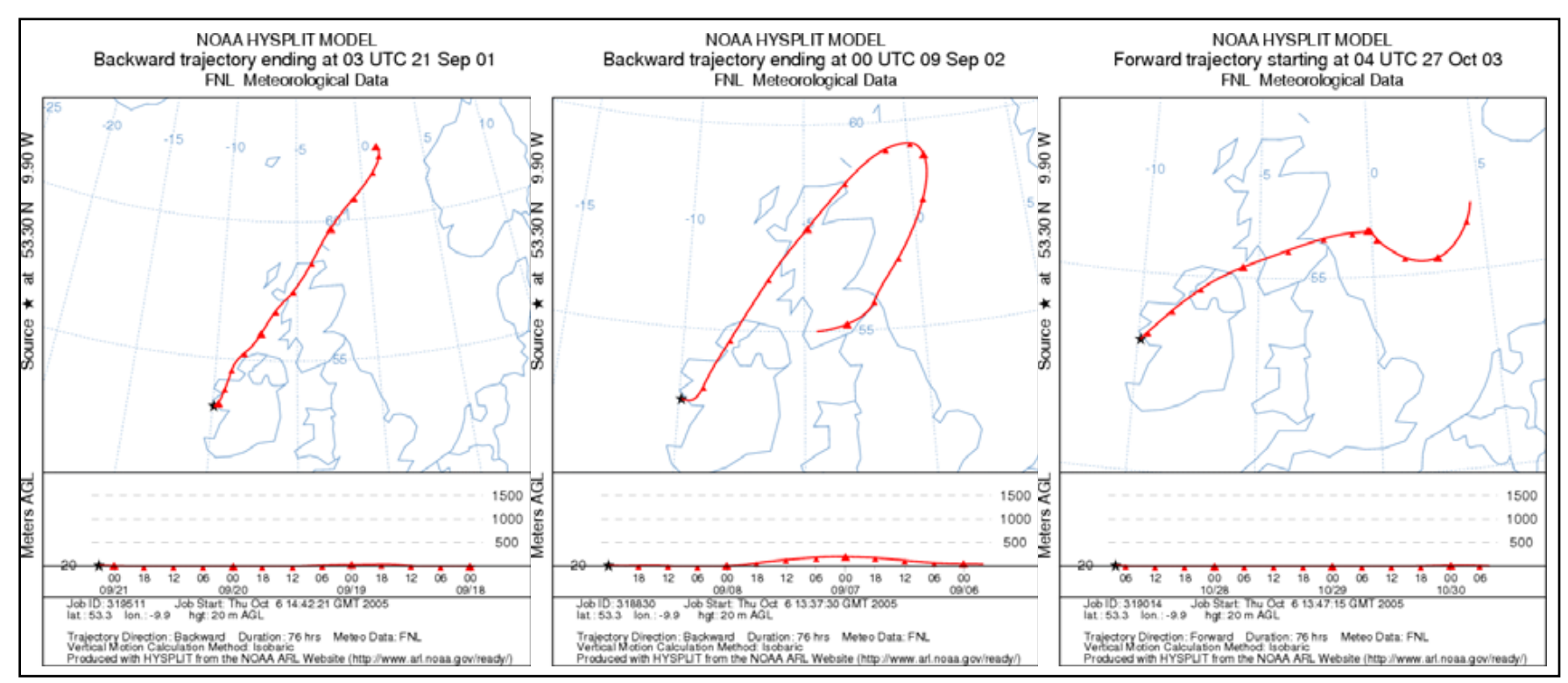

Fig. 7. NOAA HYSPLIT model 3-day back trajectories for north-easterly land-breeze events.

\section{References}

Biester, H., Keppler, F., Putschew, A., Martinez-Cortizas A., and Petri M.: Halogen retention, organohalogens, and the role of organic matter decomposition on halogen enrichment in two Chilean peat bogs, Environ. Sci. Technol., 38, 1984-1991, 2004.

Biraud, S., Ciais, P., Ramonet, M., Simmonds, P., Kazan, V., Monfray, P., O’Doherty, S., Spain, G., and Jennings, S. G.: Quantification of carbon dioxide, methane, nitrous oxide and chloroform emissions over Ireland from atmospheric observations at Mace Head, Tellus B, 54 (1), 41-60, 2002.

Carpenter, L. J. and Liss, P. S.: On temperate sources of $\mathrm{CHBr}_{3}$ and other reactive organic bromine gases, J. Geophys. Res., 105, 20 539-20 548, 2000.

Carpenter, L. J., Malin, G., Kuepper, F., and Liss, P. S.: Novel biogenic iodine-containing trihalomethanes and other short-lived halocarbons in the coastal East Atlantic, Global Biogeochem. Cycles, 14, 1191-1204, 2000.

Carpenter, L. J., Liss, P. S., and Penkett, S. A.: Marine organohalogens in the atmosphere over the Atlantic and Southern Oceans, J. Geophys. Res., 108, 4256, doi: 10.1029/2002JD002769, 2003.

Dimmer, C. H., Simmonds, P. G., Nickless, G., and Bassford, M. R.: Biogenic fluxes of halomethanes from Irish peatland ecosystems, Atmos. Environ., 35, 321-330, 2001.

Dunse, B. L., Steele, L. P., Fraser, P. J., and Wilson, S. R.: An analysis of Melbourne pollution episodes observed at Cape Grim from 1995-1998, in: Baseline Atmospheric Program (Australia) 1997-98, edited by: Tindale, N. W., Francey, R. J., and Derek, N. A., pp. 34-42, Bureau of Meteorology and CSIRO Atmospheric Research, Melbourne, Australia, 2001.

Dunse, B. L., Steele, L. P., Wilson, S. R., Fraser, P. J., Krummel, P. B.: Trace gas emissions from Melbourne, Australia, based on AGAGE observations at Cape Grim, Tasmania, 1995-2000, Atmos. Environ., 39, 6334-6344, 2005.

Dvortsov, V. L., Geller, M. A., Solomon, S., Schauffler, S. M., Atlas,
E. L., and Blake, D. R.: Rethinking reactive halogen budgets in the midlatitude lower stratosphere, Geophys. Res. Lett., 26, 1699-1702, 1999.

Gschwend, P. M., McFarlane, J. K., and Newman, K. A.: Volatile halogenated organic compounds released to seawater from temperate marine macroalgae, Science, 227, 1023-1035, 1985.

Goodwin, K. D., Lidstrom, M. E., and Oremland, R. S.: Marine bacterial degradation of brominated methanes, Environ. Sci. Technol., 31, 3188-3192, 1997.

Haselmann, K. F., Laturnus, F., Svensmark, B., and Gron, C.: Formation of chloroform in spruce forest soil - results from laboratory incubation studies, Chemosphere, 41, 1769-1774, 2000.

Helsel, D. R. and Hirsch, R. M.: Studies in environmental science 49: Statistical methods in water resources, Amsterdam, Elsevier, p. $276,1992$.

Hoekstra, E. J., De Leer, E. D. B, and Brinkman, U. A. T: Natural formation of chloroform and brominated trihalomethanes in soil, Environ. Sci. Technol., 32, 3724-3729, 1998.

Klick, S.: The release of volatile halocarbons to seawater by untreated and heavy metal exposed samples of the brown seaweed Fucus vesiculosus, Mar. Chem., 42, 211-221, 1993.

Matthews, E. and Fung, I.: Methane emission from natural wetlands: global distribution, area and environmental characteristics of sources, Global Biogeochem. Cycles, 1, 61-86, 1987.

Mtolera, M. S. P., Collen, J., Pedersen, M., Ekdahl, A., Abrahamsson, K., and Semesi, A. K.: Stress-induced production of volatile halogenated organic-compounds in Eucheumadenticulatum (Rhodophyta) caused by elevated $\mathrm{pH}$ and high light intensities, Euro. J. Phycology, 31, 89-95, 1996.

Nielsen, J. E. and Douglass, A. R.: Simulation of bromoform's contribution to stratospheric bromine, J. Geophys. Res., 106, 80898100, 2001.

Nightingale, P. D., Malin, G., and Liss, P. S.: Production of chloroform and other low-molecular-weight halocarbons by some species of macroalgae, Limnol. Oceanogr., 40, 680-689, 1995. 
O’Doherty, S., Simmonds, P. G., Cunnold, D. M., Wang, H. J., Sturrock, G. A., Fraser, P. J., Ryall, D., Derwent, R. G., Weiss, R. F., Salameh, P., Miller, B. R., and Prinn, R. G.: In-Situ Chloroform Measurements at AGAGE Atmospheric Research Stations from 1994-1998, J. Geophys. Res., 106, 20 429-20 444, 2001.

O’Doherty, S., Cunnold, D. M., Manning, A., Miller, B. R., Wang, R. H. J., Krummel, P. B., Fraser, P. J., Simmonds, P. G., McCulloch, A., Weiss, R. F., Salameh, P., Porter, L. W., Prinn, R. G., Huang, J., Sturrock, G., Ryall, D., Derwent, R. G., and Montzka, S. A.: Rapid growth of hydrofluorocarbon 134a and hydrochlorofluorocarbons 141b, 142b, and 22 from Advanced Global Atmospheric Gases Experiment (AGAGE) observations at Cape Grim, Tasmania, and Mace Head, Ireland, J. Geophys. Res., 109, D06310, doi:10.1029/2003JD004277, 2004.

Olson, J.: Global Ecosystems Database, Version 1.0: Disc A. NOAA National Geophysical Data Center, Boulder, CO, USA, World Ecosystems (WEI.4): digital raster data on a 10 minute geographic $19080 \times 2160$ grid, 1992 .

Pedersén, M., Collén, J., Abrahamsson, K., and Ekdahl, A.: Production of halocarbons from seaweeds - An oxidative stress reaction, Sci. Mar., 60, 257-263, 1996.

von Glasow, R., von Kuhlmann, R., Lawrence, M. G., Platt, U., and Crutzen, P. J.: Impact of reactive bromine chemistry in the troposphere, Atmos. Chem. Phys., 4, 2481-2497, 2004,

SRef-ID: 1680-7324/acp/2004-4-2481.

Prinn, R. G., Weiss, R. F., Fraser, P. J., Simmonds, P. G., Cunnold, D. M., Alyea, F. N., O'Doherty, S., Salameh, P., Miller, B. R., Huang, J., Wang, R. H. J., Hartley, D. E., Harth, C., Steele, L. P., Sturrock, G., Midgley, P. M., and McCulloch, A.: A history of chemically and radiatively important gases in air deduced from ALE/GAGE/AGAGE, J. Geophys. Res., 105, 17 751-17 792, 2000.
Simmonds, P. G., O’Doherty, S., Nickless, G., Sturrock, G. A., Swaby, R., Knight, P., Ricketts, J., Woffendin, G., and Smith, R.: Automated gas chromatograph-mass spectrometer for routine atmospheric field measurements of the CFC replacement compounds, the hydrofluorocarbons and hydrochlorofluorocarbons, Anal. Chem., 34, 717-723, 1995.

Sturges, W. T., Oram, D. E., Carpenter, L. J., Engel A., and Penkett, S. A.: Bromoform as a source of bromine to the stratosphere, Geophys. Res. Lett., 27, 2081-2084, 2000.

Theiler, R., Cook, J. C., Hager, L. P., and Studa, J. F.: Halohydrocarbon synthesis by bromoperoxidase, Science, 202, 1094-1096, 1978.

Quack, B. and Wallace D. W. R.: Air-sea flux of bromoform: Controls, rates, and implications, Global Biogeochem. Cycles, 17 (1), 1023, doi:10.1029/2002GB001890, 2003.

Vilter, H.: Peroxidases from Phaeophyceae .3. Catalysis of halogenation by peroxidases from Ascophyllum-Nodosum (L) LeJol, Bot. Mar., 26 , 429-435, 1983.

Wever, R., Tromp, M. G. M., Krenn, B. E., Marjani, A., and Vantol, M.: Brominating activity of the seaweed Ascophyllum-nodosum - impact on the biosphere, Environ. Sci. Tech., 25, 446-449, 1991.

Wevill, D. J. and Carpenter, L. J.: Automated measurement and calibration of reactive volatile halogenated organic compounds in the atmosphere, Analyst, 129, 634-638, 2004.

Yokouchi, Y., Barrie, L. A., Toom D., and Akimoto, H.: The seasonal variation of selected natural and anthropogenic halocarbons in the Arctic troposphere, Atmos. Environ., 30, 1723-1727, 1996. 